\title{
Pyschodermatology: a trip through history
}

\author{
Psicodermatologia: uma viagem pela história
}

\author{
Katlein França ${ }^{1}$ \\ Jessica Savas ${ }^{3}$
}

\author{
Anna Chacon ${ }^{2}$ \\ Keyvan Nouri ${ }^{4}$
}

Jennifer Ledon ${ }^{3}$

\begin{abstract}
The interaction between the mind and diseases of the skin has been the study focus for many researchers worldwide. The field of Psychodermatology, or Psychocutaneous Medicine, is the result of the merging of two major medical specialties, psychiatry and dermatology. Although the history of Psychodermatology is rather old and interesting, the field has only recently gained popularity. Since ancient times, philosophers, surgeons, dermatologists and psychiatrists have reported the presence of psychocutaneous diseases in various scenarios. In this article, the authors describe curious and remarkable facts in the history of Psychodermatology.

Keywords: Dermatology; History; Psychiatry

Resumo: A interação entre a mente e doenças de pele tem sido foco de estudo de diversos pesquisadores no mundo todo. A Psicodermatologia ou Medicina Psicocutânea é o resultado da união de duas importantes especialidades médicas: a psiquiatria e a dermatologia. A história da psicodermatologia é bastante antiga e interessante. Filósofos, cirurgiões, dermatologistas, psiquiatras relatavam, desde a antiguidade a presença de doenças psicocutâneas, em diversos cenários. Neste artigo, os autores descrevem fatos curiosos e marcantes da história da Psicodermatologia.

Palavras-chave: Dermatologia; História; Psiquiatria
\end{abstract}

The interaction between mind and skin diseases has been the study focus of many researchers worldwide. Psychodermatology, or psychocutaneous medicine, is the result of the merging of two major medical specialties: psychiatry and dermatology. Psychiatry involves the study of mental processes, which are manifested internally, while dermatology is responsible for diagnosis and treatment of skin diseases and their appendages, which are manifested externally. ${ }^{2}$ The practicing dermatologist should be aware of this relationship and consider the constant interaction between psychological and biological aspects of diseases. ${ }^{3}$ The history of Psychodermatology is rather old and interesting. Since the beginning of time, mankind has been concerned with the existence of a force that is external to the body. ${ }^{4}$ Hippocrates (460-377 BC) mentioned the relationship between stress and its effects on skin in his writings, citing cases of people who tore their hair out in response to emotional stress. Aristotle (384-322 BC) believed that the mind and body were not two separate entities, but complementary and inseparable.

In 1857, the English dermatologist and surgeon William James Erasmus Wilson wrote the book "Diseases of the Skin", in which he describes the first the so-called "skin neurosis", addressing topics such as delusions of parasitosis, alopecia areata, pruritus, and hypopigmented lesions. ${ }^{5}$ Wilson also explains that the amount of sweat loss is dependent on a number of factors that affect the body physically or through the actions of the nervous system. Thus, anxiety, depression or fear could be responsible for hyperhidrosis. ${ }^{6}$

Although mentioned by Hippocrates in antiquity, the term trichotillomania did not appear until

Received on 14.08.2012.

Approved by the Advisory Board and accepted for publication on 08.10.2012.

* Work performed at the Department of Dermatology and Cutaneous Surgery at the University of Miami, Miller School of Medicine, - Miami, USA.

Conflict of interest: None

Financial funding: None

Medical Doctor- Volunteer Faculty- Assistant Professor of the Department of Dermatology \& Cutaneous Surgery - University of Miami, Miller School of Medicine - Miami, USA.

Medical Doctor - Research Associate- Department of Dermatology and Cutaneous Surgery, University of Miami, Miller School of Medicine - Miami, USA.

Bachelor of Science - Fellow- Department of Dermatology and Cutaneous Surgery, University of Miami, Miller School of Medicine - Miami, USA.

Medical Doctor, Professor - Professor of Dermatology,Otorhinolaryngology and Ophthalmology. Director of Mohs Dermatologic and Laser Surgery, Dep. of

Dermatology and Cutaneous Surgery, University of Miami, Miller School of Medicine - Miami, USA. 
1889, when the French dermatologist Hallopeau Francois Henri (1842-1919) described the case of a patient who pulled her hair out. Other historical descriptions of trichotillomania can be found in the Bible and in the works of Shakespeare:

"At this news I tore my garment and my cloak; I tore hair from my head and beard and sat down, quite overcome." (Bible, Ezra 9:3).

"Thou canst not speak of that thou dost not feel. Wert thou as young as I, Juliet thy love. An hour but married, Tybalt murdered. Doting like me, and like me banished. Then mightst thou speak, then mightst thou tear thy hair. And fall upon the ground, as I do now. Taking the measure of an unmade grave." (Shakespeare, The Tragedy Of Romeo and Juliet, act 3, scene 3, 1959)

Clearly, history provides several examples of tearing out of hair that are always associated with situations of stress and anxiety.

Delusional parasitosis, another important focus of study in psychodermatology, was first mentioned in 1799 by the English dermatologist Robert Willan (1757-1812) and in 1801 by the physician Johann Heinrich Jordens (1764-1813). ${ }^{7}$ This disorder involves a state of phobia where patients believe falsely that they have skin parasites, leading to intense itching and excoriation. In 1894, the Persian dermatologist Thibierge Georges (1856-1926) reported a case with a detailed description of the disease, calling it "acarophobia". Although other names like entomophobia (fear of insects or arthropods) and parasitophobia (fear of parasites) have also been used, in 1938, the Swedish neurologist Karl Axel Ekbom was the first to differentiate this pathologic condition from simple fear of insects. While Ekbom termed the disorder "dermatozoic delusion," the eponym "Ekbom's syndrome" is still used today. In 1946, in a publication in the Archives of Dermatology, Wilson and Miller coined the currently accepted term "delusional parasitosis".

Body Dysmorphic Disorder is another psychodermatosis with origins that can be traced to the distant past. It is a somatoform disorder, whereby the affected person manifests an excessive concern for body image and preoccupation with perceived defects of their physical features. It was first documented in 1886 by the Italian psychopathologist Enrique Morselli under the name "dysmorphophobia." Later, Sigmund Freud also described a case involving a patient with body dysmorphia. In the book titled: "The Wolfman and Other Cases" (1909), Freud tells the story of a Russian aristocrat constantly bothered by the appearance of his nose and how this perceived physical defect negatively affected his social life. ${ }^{9}$ Despite being described for over 100 years, it was not until 1987 that Body Dysmorphic Disorder was added to the Diagnostic and Statistical Manual of Mental Disorders (DSM).

By analyzing the history of Psychodermatology, we have found very interesting and curious facts. Philosophers, surgeons, dermatologists, and psychiatrists, have long since reported the presence of psycho-cutaneous diseases in various scenarios. Although well- established as a subspecialty of dermatology, Psychodermatology has only recently gained popularity and has been increasingly studied by dermatologists worldwide over the past two decades. The understanding of the existence of a cycle, whereby psychological disturbances cause skin diseases and skin diseases cause psychological disorders, is the basis for good dermatologic practice.

In this scenario, we emphasize the idea that a dermatologist should be prepared to diagnose, provide appropriate psychological support and treat properly their patients. A good doctor-patient relationship is one of the keys to success.

\section{REFERENCES}

1. Koo JY. Psychodermatology: a practical manual for clinicians. Cur Prob Dermatol. 1995;6:204-32.

2. Rodríguez-Cerdeira C, Pera-Grasa J, A, Molares, Isa-Isa R, Arenas-Guzmán R. Psychodermatology: Past, Present and Future. Open Dermatol J. 2011;5:21-7.

3. Hoffmann FS, Zogbi H, Fleck P, Müller MC. A integração mente e corpo em psicodermatologia. Psicol Teor Prát. 2005;7:51-60.

4. Tilles $\mathrm{G}$, Wallach $\mathrm{D}$. The history of nosology in dermatology. Ann Dermatol Venereol. 1989:116:9-26

5. Koo JY, Pham CT. Psychodermatology. Practical guidelines on pharmacotherapy. Arch Dermatol. 1992;128:381-8.

6. Wilson E. On diseases of the skin. 2nd ed: London: Ed John Churchill; 1847.

7. Freudenmann RW, Lepping P. Delusional infestation. Clin Microbiol Rev. 2009:22:690-732

8. Wilson JW, Miller HE. Delusion of parasitosis. Arch Dermatol. 1946;54:39-56.

9. Freud S. The wolfman and other cases. Huish LA, translator. London: Penguin Books; 2002.

\author{
MAILING ADDRESS: \\ Katlein França \\ 1475 NW 12th Avenue, 2nd Floor \\ Miami, FL, 33136 \\ USA \\ E-mail:k.franca@med.miami.edu
}

How to cite this article: França K, Chacon A, Ledon J, Savas J, Nouri K. Pyschodermatology: a trip through history. An Bras Dermatol. 2013;88(5):842-3. 